Published July 2018

EKONOMIKAWAN : Jurnal Ilmu Ekonomi dan Studi Pembangunan

ISSN : 1693-7600 (Print), ISSN : 2598-0157 (Online), http://jurnal.umsu.ac.Id/index.php/ekawan

\title{
Analisis Faktor yang Berpengaruh terhadap Ketimpangan Pendapatan di Indonesia
}

\author{
Yudhistira Ardana \\ Sistem Informasi, STMIK Pringsewu \\ Wonodadi, Gading Rejo, Kabupaten Pringsewu, Lampung 35372 \\ e-mail:ardanayudhistira@gmail.com
}

\begin{abstract}
ABSTRAK
Penelitian ini bertujuan untuk menganilisis faktor apa saja yang berdampak terhadap ketimpangan pendapatan di Indonesia. Metode yang digunakan dalam penelitian ini adalah melakukan analisis regresi data panel dengan menggunakan bantuan E-views 10. Variabel yang digunakan dalam penelitian ini yaitu Data Rasio Gini sebagai variabel Y, sedangkan Pendapatan Asli Daerah, Dana Alokasi Umum, Belanja Modal, Sumbangan Sektor Pertanian, Sumbangan Sektor Manufaktur, Sumbangan Sektor Jasa, Sumbangan Sektor Keuangan, Penanaman Modal Dalam Negeri dan Penanaman Modal Asing sebagai variabel X. Provinsi yang digunakan dalam penelitian ini sebanyak 32 provinsi. Hasil penelitian, variabel yang berpengaruh terhadap penurunan ketimpangan distribusi pendapatan adalah DAU, belanja modal, sumbangan sektor pertanian, sumbangan sektor manufaktur dan sumbangan sektor keuangan. Sedangkan PAD, sektor jasa, PMDN dan PMA, berpengaruh positif terhadap peningkatan ketimpangan distribusi pendapatan.
\end{abstract}

Kata kunci : PDRB, Pendapatan Asli Daerah, Dana Alokasi Umum, Belanja Modal, Penanaman Modal Asing, Penanaman Modal Dalam Negeri, Ketimpangan Distribusi Pendapatan 
Published July 2018

EKONOMIKAWAN : Jurnal Ilmu Ekonomi dan Studi Pembangunan

ISSN : 1693-7600 (Print), ISSN : 2598-0157 (Online), http://jurnal.umsu.ac.Id/index.php/ekawan

\title{
Analysis of Factors that Influence Income Inequality in Indonesia
}

\begin{abstract}
This study aims to analyze what factors affect the income inequality in Indonesia. The method used in this research is to perform regression analysis of panel data using E-views 10. The variables used in this study are Gini Ratio as Y variable, while Local Revenue, General Allocation Fund, Capital Expenditure, Agricultural Sector Contribution, Contribution of Manufacturing Sector, Service Sector Contribution, Financial Sector Contribution, Domestic Investment and Foreign Investment as variable X. The province used in this research is 32 provinces. The result of the research, the variables that influence the decreasing inequality of income distribution are DAU, capital expenditure, contribution of agriculture sector, contribution of manufacturing sector and financial sector contribution. While PAD, service sector, PMDN and PMA, positively influence to increase inequality income distribution.
\end{abstract}

Keywords: PDRB, Local Revenue, General Allocation Fund, Capital Expenditure, Foreign Investment, Domestic Investment, Inequality of Revenue Distribution

\section{PENDAHULUAN}

Di era ekonomi modern saat ini, telah terbukti secara empiris bahwa mekanisme pasar tidak dapat berjalan sendiri tanpa peran pemerintah untuk mencapai kondisi perekonomian yang optimal. Kondisi ini memberikan legitimasi bagi pemerintah untuk mengambil peran yang lebih banyak dalam membuat kebijakan ekonomi agar manfaat dari perekonomian dapat dirasakan oleh seluruh komponen masyarakat. Fungsi utama yang dijalankan oleh pemerintah tersebut bertujuan untuk mencapai kesejahteraan masyarakat yang berkeadilan. Dalam beberapa teori ekonomi pembangunan, untuk mencapai kesejahteraan tersebut dapat ditempuh dengan pembangunan ekonomi.

Pembangunan ekonomi merupakan tahapan proses yang mutlak dilakukan oleh suatu bangsa untuk dapat meningkatkan taraf hidup dan kesejahteraan seluruh rakyat bangsa tersebut. Pembangunan ekonomi suatu negara tidak dapat hanya dilakukan dengan berbekal tekad yang membaja dari seluruh rakyatnya untuk membangun, tetapi lebih dari itu harus didukung pula oleh ketersediaan sumberdaya ekonomi, baik sumberdaya alam, sumberdaya manusia, dan sumberdaya modal, yang produktif. Dengan kata lain, tanpa adanya daya dukung yang cukup kuat dari sumberdaya ekonomi yang produktif, maka pembangunan ekonomi mustahil dapat dilaksanakan dengan baik dan memuaskan. 
Published July 2018

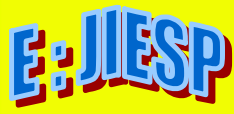

EKONOMIKAWAN : Jurnal Ilmu Ekonomi dan Studi Pembangunan

ISSN : 1693-7600 (Print), ISSN : 2598-0157 (Online), http://jurnal.umsu.ac.Id/index.php/ekawan

Pembangunan ekonomi di Indonesia diarahkan untuk mewujudkan masyarakat yang semakin sejahtera, makmur dan berkeadilan. Pembangunan ekonomi daerah adalah suatu proses dimana pemerintahan daerah dan masyarakatnya mengelola sumber-sumber daya yang ada dan membentuk suatu pola kemitraan antara daerah dan sektor swasta untuk menciptakan suatu lapangan pekerjaan dan merangsang perkembangan kegiatan ekonomi di dalam wilayah tersebut.

Menurut Sukirno (2010), dalam kegiatan perekonomian yang sebenarnya pertumbuhan ekonomi berarti perkembangan fisikal barang dan jasa yang berlaku di suatu negara, seperti pertambahan dan jumlah produksi barang industri, perkembangan infrastruksur, pertambahan jumlah sekolah, pertambahan produksi sektor jasa dan pertambahan produksi barang modal. Tetapi dengan menggunakan berbagai jenis data produksi adalah sangat sukar untuk memberi gambaran tentang pertumbuhan ekonomi yang dicapai. Oleh sebab itu untuk memberikan suatu gambaran kasar mengenai pertumbuhan ekonomi yang dicapai suatu negara, ukuran yang selalu digunakan adalah tingkat pendapatan nasional riil yang dicapai.

Indikator keberhasilan pembangunan suatu negara bisa dilihat laju pertumbuhan ekonominya. Karena itu, setiap negara selalu menetapkan target laju pertumbuhan yang tinggi di dalam perencanaan dan tujuan pembangunan negaranya. Pertumbuhan ekonomi yang tinggi dan berkelanjutan merupakan kondisi utama bagi kelangsungan pembangunan ekonomi. Karena penduduk bertambah terus, maka "dibutuhkan penambahan pendapatan setiap tahunnya, hal ini dapat terpenuhi lewat peningkatan output secara agregat baik barang maupun jasa atau Produk Domestik Bruto (PDB) setiap tahunnya" (Kusuma, 2011). Pulau Jawa merupakan wilayah dengan jumlah penduduk terbanyak di Indonesia. Selain itu pusat kegiatan ekonomi dan pemerintahan juga berada di pulau Jawa yang membuat produk domestik regional bruto (PDRB) lebih tinggi dibandingkan dengan daerah lainnya. Sebagai wilayah dengan PDRB tertinggi maka tidak mengherankan perkembangan perekonomian di wilayah terus mengalami peningkatan. Gambar 1 memperlihatkan proporsi PDRB yang dihasilkan oleh beberapa wilayah/pulau di Indonesia berdasarkan harga konstan 2000 antara tahun 2007-2012.

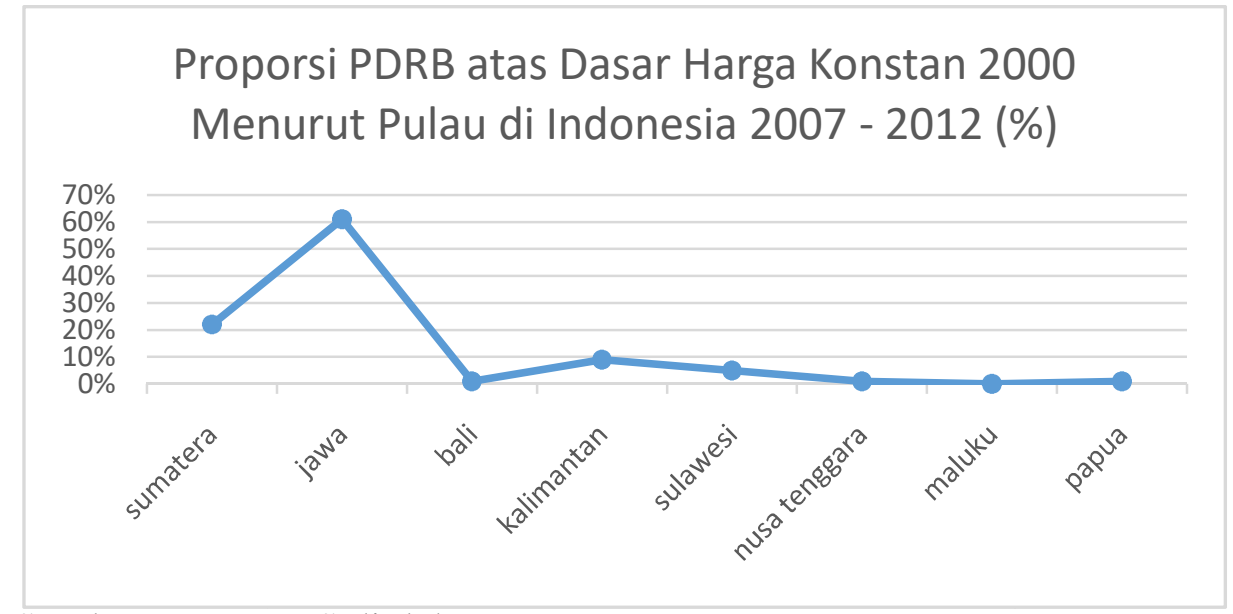

Sumber : Data BPS diolah

Gambar 1

Proporsi PDRB antar Pulau di Indonesia 
Published July 2018

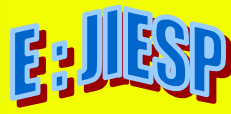

EKONOMIKAWAN : Jurnal Ilmu Ekonomi dan Studi Pembangunan

ISSN : 1693-7600 (Print), ISSN : 2598-0157 (Online), http://jurnal.umsu.ac.ld/index.php/ekawan

Dari data di atas dapat diketahui bahwa tingkat prosentase proporsi PDRB di Indonesia yang paling besar adalah di Pulau Jawa yaitu sebesar 61\%. Selanjutnya diikuti oleh Pulau Sumatera (22\%), Kalimantan (9\%), Sulawesi (5\%), Bali, Nusa Tenggara dan Papua (1\%) serta Maluku (0\%). Pembangunan ekonomi suatu negara dinyatakan berhasil jika terjadinya pertumbuhan ekonomi yang diiringi dengan berkurangnya ketimpangan pendapatan. Salah satu indikator untuk mengukur ketimpangan tersebut yaitu menggunakan ratio gini yang memiliki nilai 0 sampai dengan 1 . Rasio gini kecil lebih kecil dari 0,4 menunjukkan ketimpangan rendah, nilai 0,4-0,5 menunjukkan tingkat ketimpangan sedang dan nilai lebih besar dari 0,5 menunjukkan tingkat ketimpangan tinggi.Berikut disajikan grafik perkembangan ketimpangan di Indonesia tahun 2014-2017.

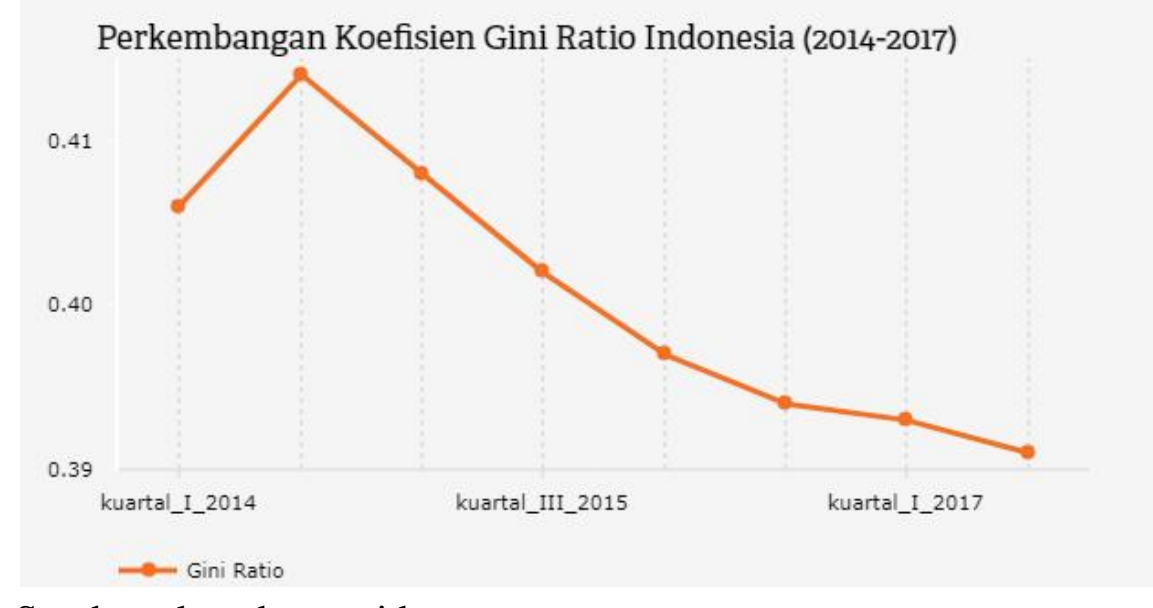

Sumber : katadata.co.id

\section{Gambar 2 \\ Grafik Perkembangan Koefisien Gini Ratio}

Ketimpangan distribusi pendapatan adalah suatu kondisi dimana distribusi pendapatan yang diterima masyarakat tidak merata. Ketimpangan dalam distribusi pendapatan menggambarkan bahwa hanya sebagian besar masyarakat yang terdiri dari karyawan dan buruh hanya menikmati sedikit dari pendapatan nasional. Permasalahan ketimpangan distribusi pendapatan tersebut merupakan suatu masalah yang penting dan harus segera diatasi karena ketimpangan pendapatan berdampak bukan hanya dalam hal ekonomi tetapi juga dalam hal sosial. Todaro (2010) menyebutkan dua alasan mengapa ketimpangan harus diperhatikan yaitu, ketimpangan yang ekstrem dapat meyebabkan inefisiensi ekonomi serta melemahkan stabilitas sosial dan solidaritas.

Ketimpangan distribusi pendapatan antar golongan masyarakat membahas kesenjangan antara golongan yang berpendapatan tinggi dan golongan yang berpendapatan rendah (Kuncoro, 2015: 97). Sismosoemarto (2012) mengungkapkan bahwa akibat adanya masalah ini adalah munculnya kecemburuan sosial, ketegangan, dan terus memicu kesenjangan. Sehingga masyarakat mengalami frustasi sosial yang kemudian berujung pada tindak kriminal atau kekerasan lainnya (Kuncoro, 2015: 98). Adapun ketimpangan pendapatan regional merupakan ketimpangan perkembangan ekonomi antar berbagai daerah pada suatu wilayah yang kemudian menyebabkan ketimpangan pendapatan per kapita antar daerah (Nikijuluw, 2014: 5). 
Published July 2018

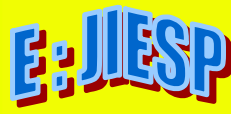

EKONOMIKAWAN : Jurnal Ilmu Ekonomi dan Studi Pembangunan

ISSN : 1693-7600 (Print), ISSN : 2598-0157 (Online), http://jurnal.umsu.ac.ld/index.php/ekawan

Pembangunan dalam lingkup spasial memang tidak selalu merata, ketimpangan pendapatan antar wilayah menjadi salah satu permasalahan yang sangat serius. Pertumbuhan ekonomi yang telah dicapai tidak mampu untuk mengatasi masalah yang timbul akibat belum meratanya pembangunan dikarenakan juga terdapat beberapa daerah yang mengalami pertumbuhan ekonomi yang cepat, tetapi beberapa daerah yang lain mengalami pertumbuhan ekonomi yang lambat. Menurut Nazara (2010) disparitas antar daerah adalah masalah struktural di perekonomian Indonesia. Dimana selama empat dekade pembangunan ekonomi tidak terjadi perubahan yang berarti dalam distribusi pendapatan antar daerah. Hal ini terjadi bersamaan dengan peningkatan pendapatan nasional dan pendapatan perkapita dalam kerangka proses akumulasi, alokasi dan transisi demografi. Mengingat cukup besar dampak yang ditimbulkan akibat ketimpangan distribusi pendapatan, maka diperlukan kajian mengenai faktor-faktor yang mempengaruhi permasalahan ketimpangan distribusi pendapatan di Indonesia.

\section{METODE}

Jenis penelitian ini merupakan penelitian deskriptif kuantitatif yaitu penelitian tentang data yang dikumpulkan dan dinyatakan dalam bentuk angka-angka. Jenis data yang digunakan dalam penelitian ini adalah data sekunder. Fokus penelitian ini adalah ingin melihat faktor apa saja yang mempengaruhi ketimpangan pendapatan di Indonesia. Teknik pengambilan sampel menggunakan purposive sampling. Teknik purposive sampling ini digunakan untuk mendapatkan sampel yang sesuai dan bersifat sama antar sampel satu dengan sampel lainnya. Disamping itu juga karena keterbatasan akses data dari peneliti karena tidak semua provinsi memiliki data dengan jumlah tahun yang sama. Provinsi yang digunakan pada penelitian ini adalah provinsi di atas tahun 2007 yang telah mempunyai kelengkapan data dan publikasi yaitu sebanyak 32 Provinsi yang ada di Indonesia. Data rasio gini, Pendapatan Asli Daerah, Dana Alokasi Umum, Belanja Modal, Sumbangan Sektor Pertanian, Sumbangan Sektor Manufaktur, Sumbangan Sektor Jasa, Sumbangan Sektor Keuangan, Penanaman Modal Dalam Negeri dan Penanaman Modal Asing.

Metode yang digunakan dalam penelitian ini adalah melakukan analisis regresi data panel dengan menggunakan bantuan E-views 10. Data panel merupakan gabungan antara data silang (cross-section) dengan data runtut waktu (time series). Penggunaan data panel dapat menjelaskan dua macam informasi yaitu informasi antar unit (cross section) pada perbedaan antar subjek, dan informasi antar waktu (time series) yang mereflesikan perubahan pada subjek waktu. Dalam metode data panel persamaan model dengan menggunakan data cross-section dapat ditulis sebagai berikut :

$$
\begin{aligned}
& \text { GINIit }=\beta 0+\beta 1(\mathrm{PAD}) \text { it }+\beta 2(\mathrm{DAU}) \text { it }+\beta 3(\mathrm{BM}) \text { it }+\beta 4(\mathrm{PP}) \text { it }+\beta 5(\mathrm{PM}) \text { it }+\beta 6(\mathrm{PJ}) \text { it }+ \\
& \beta 7(\mathrm{PK}) \text { it }+\beta 8(\mathrm{PMDN}) i \mathrm{t}+\beta 9(\mathrm{PMA}) \text { it }+ \text { eit }
\end{aligned}
$$

Keterangan :

$$
\begin{array}{ll}
\text { GINIit } & =\text { Variabel Dependen (Y) } \\
\beta 0 & =\text { Konstanta } \\
\beta 1, \beta 2, \beta 3, \ldots & =\text { Koefisien variabel Independen } \\
\text { PADit } & =\text { Pendapatan Asli Daerah (X1) } \\
\text { DAUit } & =\text { Dana Alokasi Umum (X2) } \\
\text { BMit } & =\text { Belanja Modal (X3) }
\end{array}
$$


Published July 2018

בd] EKONOMIKAWAN : Jurnal Ilmu Ekonomi dan Studi Pembangunan

ISSN : 1693-7600 (Print), ISSN : 2598-0157 (Online), http://jurnal.umsu.ac.Id/index.php/ekawan

PPit $\quad=$ Sumbangan Sektor Pertanian $(X 4)$

PMit = Sumbangan Sektor Manufaktur (X5)

PJit $\quad=$ Sumbangan Sektor Jasa (X6)

PKit $\quad=$ Sumbangan Sektor Keuangan $(X 7)$

PMDNit = Penanaman Modal Dalam Negeri (X8)

PMAit $\quad=$ Penanaman Modal Asing (X9)

Eit $\quad=$ Error

Dalam mengestimasi regresi data panel terdapat tiga pendekatan yang dapat digunakan yaitu Metode Model Common Effect, model Fixed Effect, dan model Random Effect. Pemilihan model yang akan digunakan dalam sebuah penelitian sangat perlu dilakukan berdasarkan pertimbangan statistik. Hal ini ditujukan untuk memperoleh dugaan yang efisien. Dan beberapa metode yang paling baik untuk digunakan adalah:

1. Chow Test (uji F-statistik) adalah pengujian untuk memilih model Common Effect (tanpa variabel dummy) atau dengan model Fixed Effect.

2. Uji Langrange Multipler (LM) atau lengkapnya TheBreusch-Pagan LM Test.

Digunakan untuk memilih model Common Effect (tanpa variabel dummy) atau dengan model Random Effect.

3. Dan yang terakhir dengan menggunakan uji Hausman untuk membandingkan antara model Fixed Effect atau Random Effect yang lebih baik digunakan.

\section{HASIL PENELITIAN DAN PEMBAHASAN}

\section{Chow Test (Uji F-statistik)}

Uji Chow dapat digunakan untuk mengetahui apakah model FEM lebih baik dibandingkan model PLS dapat dilakukan dengan melihat signifikasi model FEM dapat dilakukan dengan uji statistik F.

Tabel 1

Uji Chow

\begin{tabular}{lrrr}
\hline \hline Effects Test & Statistic & d.f. & Prob. \\
\hline \hline Cross-section F & 10.844118 & $(31,279)$ & 0.0000 \\
Cross-section Chi-square & 253.018587 & 31 & 0.0000 \\
\hline \hline
\end{tabular}

Pada hasil uji chow di atas dapat dilihat bahwa probabilitas $\mathrm{F}$ adalah sebesar 0.0000. $\mathrm{Hal}$ ini menunjukan bahwa signifikan pada tingkat $(\mathrm{a})=5 \%$ karena nilai $\mathrm{F}$ lebih kecil dari $\mathrm{a}=5 \%$. Maka $\mathrm{H} 1$ diterima dan $\mathrm{H} 0$ ditolak sehingga model data yang digunakan adalah Fixed Effect Model.

\section{Hausman Test}

Setelah diketahui bahwa model yang digunakan adalah fixed effect model, model data panel dibandingkan antara fixed effect model dengan random effect. Uji hausman digunakan untuk mengetahui apakah model fixed effect lebih baik dari model random effect. 
Published July 2018

\section{נגי EKONOMIKAWAN : Jurnal Ilmu Ekonomi dan Studi Pembangunan ISSN : 1693-7600 (Print), ISSN : 2598-0157 (Online), http://jurnal.umsu.ac.id/index.php/ekawan}

Tabel 2

Uji Hausman

\begin{tabular}{llrr}
\hline \hline Test Summary & \multicolumn{1}{c}{$\begin{array}{l}\text { Chi-Sq. } \\
\text { Statistic }\end{array}$} & Chi-Sq. d.f. & Prob. \\
\hline \hline Cross-section random & 31.231151 & 9 & 0.0003 \\
\hline \hline
\end{tabular}

Pada hasil uji hausman di atas dapat dilihat bahwa untuk Random Effect dengan Fixed Effect diperoleh probabilitas Cross section random sebesar $0.0003<\mathrm{a}=5 \%$, sehingga dapat disimpulkan bahwa model yang dapat digunakan adalah fixed effect model.

\section{Hasil Estimasi Model Fixed Effect}

Tabel 3

Hasil Estimasi Model Fixed Effect

\begin{tabular}{crrrr}
\hline \hline \multicolumn{1}{c}{ Variable } & Coefficient & Std. Error & t-Statistic & Prob. \\
\hline \hline C & 0.378710 & 0.041739 & 9.073346 & 0.0000 \\
X1? & $-1.18 \mathrm{E}-10$ & $2.27 \mathrm{E}-09$ & -0.052208 & 0.9584 \\
X2? & $7.13 \mathrm{E}-08$ & $1.60 \mathrm{E}-07$ & 0.446266 & 0.6558 \\
X3? & $-5.46 \mathrm{E}-08$ & $2.71 \mathrm{E}-08$ & -2.013479 & 0.0450 \\
X4? & -0.479947 & 0.085661 & -5.602888 & 0.0000 \\
X5? & -0.008389 & 0.027898 & -0.300713 & 0.7639 \\
X6? & 0.266679 & 0.112085 & 2.379250 & 0.0180 \\
X7? & -0.185721 & 0.360171 & -0.515646 & 0.6065 \\
X8? & $5.47 \mathrm{E}-07$ & $4.26 \mathrm{E}-07$ & 1.283542 & 0.2004 \\
X9? & $5.78 \mathrm{E}-06$ & $3.37 \mathrm{E}-06$ & 1.714267 & 0.0876 \\
\hline \hline R-squared & 0.657397 & Mean dependent var & 0.357375 \\
Adjusted R-squared & 0.608279 & S.D. dependent var & 0.041067 \\
S.E. of regression & 0.025703 & Akaike info criterion & -4.365284 \\
Sum squared resid & 0.184318 & Schwarz criterion & -3.882468 \\
Log likelihood & 739.4454 & Hannan-Quinn criter. & -4.172486 \\
F-statistic & 13.38386 & Durbin-Watson stat & 1.005975 \\
Prob(F-statistic) & 0.000000 & & & \\
\hline \hline
\end{tabular}

Dari hasil pengolahan regresi data panel diatas diketahui bahwa nilai koefisien determinasi (R-Squared) dari hasil estimasi sebesar 0.657397, yang menunjukkan variabelvariabel independen mampu menjelaskan $65.73 \%$ terhadap variabel dependen, sedangkan sisanya dijelaskan di luar model. 
Published July 2018

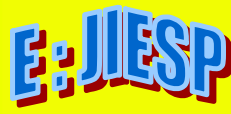

EKONOMIKAWAN : Jurnal Ilmu Ekonomi dan Studi Pembangunan

ISSN : 1693-7600 (Print), ISSN : 2598-0157 (Online), http://jurnal.umsu.ac.ld/index.php/ekawan

Dari regresi data panel menggunakan fixed effect di ketahui bahwa koefisien regresi pendapatan asli daerah 7.13 dengan nilai probabilitas 0.6558 . Hasil estimasi regresi data panel menunjukkan bahwa pendapatan asli daerah tidak berpengaruh terhadap ketimpangan distribusi. Hasil ini tidak sesuai dengan penelitian yang dilakukan oleh Valentina (2014), bahwa pendapatan asli daerah berpengaruh terhadap ketimpangan distribusi pendapatan dalam artian pendapatan asli daerah meningkat, maka distribusi pendapatan akan meningkat.

Dari regresi data panel menggunakan fixed effect diketahui bahwa koefisien regresi dana alokasi umum -1.18 dengan nilai probabilitas 0.9584. Jika dana alokasi umum mengalami kenaikan maka distribusi pendapatan akan membaik. Penyebaran dana alokasi yang besar dapat mengurangi kesenjangan antar kabupaten/kota. Kondisi yang terjadi pada setiap provinsi di Indonesia tidak mencerminkan transfer pemerintahan berupa DAU semakin merata. Terlihat dari DAU tiap tahunnya mengalami peningkatan tetapi ketimpangan yang ada cenderung meningkat pula, ini berarti DAU belum mampu menekan ketimpangan.

Dari regresi panel menggunakan fixed effect diketahui bahwa koefisien regresi belanja modal -5.46 dengan nilai probabilitas 0.0450 . Hasil ini sesuai dengan penelitian yang dilakukan oleh Valentina (2014), bahwa belanja modal berpengaruh terhadap ketimpangan distribusi pendapatan dalam artian jika belanja modal meningkat, maka ketimpangan distribusi pendapatan menurun.

Dari regresi data panel menggunakan fixed effect di ketahui bahwa koefisien regresi sumbangan sektor pertanian sebesar -0.479 dengan nilai probabilitas 0.0000 . Dengan nilai koefsien negatif menunjukkan bahwa setiap kenaikan pada sektor pertanian akan menurunkan ketimpangan pendapatan. Sumbangan sektor pertanian bagi masyarakat indonesia merupakan sumber pendapatan bagi rumah tangga yang berpendapatan rendah. Dengan demikian sumbangan sektor pertanian dapat mengurangi jumlah pengangguran dan pengurangan ketimpangan distribusi pendapatan dapat secara efektif dilakukan melalui pembangunan pertanian.

Dari regresi data panel menggunakan fixed effect diketahui bahwa koefisien regresi sumbangan sektor industri pengolahan atau manufaktur adalah sebesar -0.008 dan nilai probabilitasnya 0.7639 yang berarti jika sektor maufaktur mengalami peningkatan maka terjadi penurunan ketimpangan pendapatan. Ini berarti sumbangan sektor industri pengolahan atau manufaktur berperan dalam mengurangi ketimpangan distribusi pendapatan dikarenakan kenaikan porsi sektor manufaktur diikuti kenaikan porsi tenaga kerja sehingga tidak timpang.

Nilai koefisien regresi sektor jasa sebesar 0.266 dan nilai probabilitas sebesar 0.0180 yang artinya sumbangan sektor jasa meningkat maka distribusi ketimpangan pendapatan juga akan ikut meningkat. Pertumbuhan ekonomi sumbangan sektor jasa yang pesat pada umumnya disumbang oleh pertumbuhan sektor perdagangan, hotel dan restoran serta sektor pengangkutan dan komunikasi. Hal ini dikarenakan semakin tumbuh pesatnya produk-produk alat komunikasi. Namun sayangnya hal tersebut hanya dimanfaatkan untuk kepuasan pribadi dan belum menyentuh usaha produktif, sehingga tidak berdampak kepada pemertaan pendapatan antar daerah. 
Published July 2018

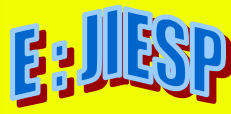

EKONOMIKAWAN : Jurnal Ilmu Ekonomi dan Studi Pembangunan

ISSN : 1693-7600 (Print), ISSN : 2598-0157 (Online), http://jurnal.umsu.ac.Id/index.php/ekawan

Nilai koefisien regresi sektor keuangan sebesar -0.1857 dan nilai probabilitas sebesar 0.6065 menunjukkan bahwa jika sumbangan sektor keuangan mengalami peningkatan maka terjadi penurunan ketimpangan pendapatan. Hal ini sesuai dengan hipotesis yang digunakan jika jasa yang dihasilkan meningkat per satuan waktu maka produktivitas tenaga kerja meningkat sehingga akan meningkatkan pendapatan. Peningkatan pendapatan ini akan meningkatkan kesejahteraan sehingga distribusi pendapatan semakin membaik.

Berdasarkan model estimasi fixed effect, diketahui bahwa variabel penanaman modal asing mempunyai pengaruh yang signifikan pada taraf 10 persen terhadap ketimpangan distribusi pendapatan dengan nilai probabilitas sebesar 0.0876 dan memiliki koefisien yang positif terhadap ketimpangan pendapatan antar provinsi sebesar 5.78 artinya apabila penanaman modal asing meningkat sebesar 1 persen, maka ketimpangan pendapatan akan meningkat sebesar $5.78 \%$. Penanaman modal asing bukan hanya mempengaruhi pertumbuhan ekonomi, akan tetapi penanamaman modal asing pun mempengaruhi ketimpangan distribusi pendapatan, hal ini sejalan dengan penelitian Nunnenkam (2011) yang menyatakan bahwa penanaman modal asing (PMA) berpengaruh positif dalam jangka waktu pendek dan berpengaruh negatif dalam jangka waktu panjang terhadap ketimpangan distribusi pendapatan.

Berdasarkan model estimasi fixed effect diketahui bahwa variabel penanaman modal dalam negeri tidak mempunyai pengaruh yang signifikan terhadap ketimpangan distribusi pendapatan. Nilai koefisien regresi penanaman modal dalam negeri adalah sebesar 5.47 dan nilai probabilitasnya 0.2004 menunjukkan peningkatan sebesar 1 persen pada variabel ini akan meningkatkan rasio gini 5.47 persen. Jadi dapat disimpulkan bahwa variabel penanaman modal dalam negeri dapat memperburuk ketimpangan distribusi pendapatan.

\section{SIMPULAN}

1. Variabel yang berpengaruh terhadap penurunan ketimpangan distribusi pendapatan adalah DAU, belanja modal, sumbangan sektor pertanian, sumbangan sektor manufaktur, sumbangan sektor keuangan. Sedangkan PAD, sektor jasa, PMDN dan PMA, berpengaruh positif terhadap peningkatan ketimpangan distribusi pendapatan.

2. Kenaikan pendapatan pada DAU, belanja modal, sumbangan sektor pertanian, sumbangan sektor manufaktur, sumbangan sektor keuangan dapat memperbaiki ketimpangan distribusi pendapatan. Sedangkan kenaikan pada PAD, sekor jasa, PMDN dan PMA, dapat memperburuk distribusi pendapatan.

\section{DAFTAR PUSTAKA}

Badan Pusat Statistik. 2007. Statistik Keuangan Indonesia 2007-2008. Indonesia : Badan Pusat Statistik.

Badan Pusat Statistik. 2009. Statistik Keuangan Indonesia 2009-2010. Indonesia : Badan Pusat Statistik.

Badan Pusat Statistik. 2011. Statistik Keuangan Indonesia 2011-2012. Indonesia : Badan Pusat Stataistik.

Badan Pusat Statistik. 2014. Statistik Keuangan Indonesia 2014-2015. Indonesia : Badan Pusat Statistik.

Badan Pusat Statistik. 2015. Produk Domestik Regional Bruto Provinsi-Provinsi di Indonesia Menurut Lapangan Usaha 2010-2014. Indonesia : Badan Pusat Statistik. 
Published July 2018

\section{EKONOMIKAWAN : Jurnal Ilmu Ekonomi dan Studi Pembangunan}

ISSN : 1693-7600 (Print), ISSN : 2598-0157 (Online), http://jurnal.umsu.ac.Id/index.php/ekawan

Badan Pusat Statistik. 2017. Produk Domestik Regional Bruto Provinsi-Provinsi di Indonesia Menurut Lapangan Usaha 2012-2016. Indonesia : Badan Pusat Statistik.

Herzer, "Dierk and Peter Nunnenkamp. 2011. FDI and Income Inequality: Evidence from Europe". Kiel Working Paper no 1675 page 1-21.

Kuncoro, M. 2015. Mudah Memahami dan Menganalisis Indikator Ekonomi. Yogyakarta: UPP STIM YKPN.

Kusuma, Rendi Hangga. 2011. Analisis Struktur Pertumbuhan Ekonomi dan Ketimpangan Pendapatan Antar Daerah di Provinsi Jawa Tengah 2004-2008. Jurnal. Universitas Negeri Surakarta

Nazara, Suahasil. 2010. Ekonomi Informal di Indonesia: Ukuran. Komposisi dan Evolusi. Organisasi Perburuhan Internasional (International Labor Organization, ILO). Jakarta.

Nikijuluw, J. B. 2014. Pertumbuhan dan Ketimpangan Pembangunan Antar Daerah Di Provinsi Maluku. Cita Ekonomika Jurnal Ekonomi Volume VIII, Nomor 1 , 1-14.

Siswosoemarto, Rubijanto. 2012. Intelejen Ekonomi: Teori dan Aplikasi. Jakarta: PT Gramedia Pustaka Utama.

Sukirno, Sadono. 2010. Makroekonomi Teori Pengantar. Jakarta : Raja Grafindo Persada. Todaro M.P dan Smith SP. 2010. Pembangunan Ekonomi. Jakarta : Erlangga.

Valentina, Putu dan Shanty. 2014. Pengaruh Pendapatan Asli Daerah, Dana Alokasi Umum dan Belanja Modal Terhadap Ketimpangan Distribusi Pendapatan. Jurnal Ekonomi Pembangunan. Volume 4, No. 1, 41-49. 